\title{
Psychosocial and Mental Health Care in Rural Environments
}

\author{
Mauricio Cirilo da Costa Neto ${ }^{1}$ \\ Magda Dimenstein \\ Federal University of Rio Grande do Norte, Natal, RN, Brazil
}

\begin{abstract}
Rural populations have historically suffered the effects of a socio-economic model based on country estates and exploitation of workers. Such model is associated with the appearance of psychosocial and environmental vulnerabilities that have a negative impact on mental health. Therefore, in rural environments there are certain conditions that play a major role in the health-disease process and must be considered in health care planning. This theoretical study discusses the case of mental health care from the perspective of social determinants of health considering the concrete territories of rural populations. We conducted a literature review using relevant databases, which demonstrated a lack of studies about the chosen topic. The territorial and community logic supporting psychosocial care must be introduced in daily care services. Such process will provide more effective solutions to the mental health needs of rural populations, which are directly related to the iniquities that have shaped life in the countryside.
\end{abstract}

Keywords: Comprehensive health care, mental health, mental health services, rural health, rural health services.

\section{Cuidado Psicossocial em Saúde Mental em Contextos Rurais}

\section{Resumo}

As populações rurais sofrem historicamente efeitos do modelo socioeconômico pautado no latifúndio e exploração do trabalhador. Esse modelo está associado à produção de situações de vulnerabilidade psicossocial e ambiental que impactam negativamente na saúde mental. No meio rural há, portanto, certos condicionantes que são decisivos no processo saúde-doença e que devem ser considerados na produção da atenção. Este estudo teórico problematiza o cuidado em saúde mental em contextos rurais considerando o processo de determinação social da saúde e da vida, bem como os territórios concretos de existência das populações rurais. Realizou-se uma revisão da literatura nos principais bancos de dados, o que evidenciou a carência de estudos sobre a temática. Considera-se que a lógica territorial e comunitária que sustenta a Atenção Psicossocial precisa ser construída no cotidiano das equipes, visando respostas mais efetivas às necessidades de saúde mental das populações rurais, relacionadas diretamente às iniquidades que marcam a vida no campo.

Palavras-chave: Assistência integral à saúde, saúde da população rural, saúde mental, serviços de saúde mental, serviços de saúde rural.

Mailing address: Federal University of Rio Grande do Norte, Rua Ary Parreiras, 224, Alecrim, Natal, RN, Brazil 59040-220. E-mail: mauricioneto_2@msn.com and mgdimenstein@gmail.com Financing: Coordination for the Improvement of Higher Education Personnel (CAPES). 


\section{Cuidado Psicosocial en la Salud Mental en Entornos Rurales}

\section{Resumen}

Las poblaciones rurales históricamente sufren efectos del modelo socio-económico basado en el latifundio y la explotación de los trabajadores. Este modelo se asocia con la producción de vulnerabilidades psicosociales y ambientales que impactan negativamente en la salud mental. En las zonas rurales, por lo tanto, existen ciertas condiciones que son decisivas en el proceso salud-enfermedad y deben ser consideradas en la producción de la atención. Este estudio teórico se ocupa de la atención en salud mental, teniendo en cuenta los determinantes sociales de la salud y la vida, así como las condiciones concretas de existencia de las poblaciones rurales. Se realizó una revisión bibliográfica en las bases de datos, lo que demuestra la falta de estudios sobre el tema. Se considera que la lógica territorial y comunitaria que orienta la atención psicosocial debe hacer parte de la vida diaria de los equipos, buscando respuestas más eficaces a las necesidades de salud mental de las poblaciones rurales, directamente relacionadas con las desigualdades sociales que marcan la vida en el campo.

Palabras clave: Atención integral de salud, salud mental, salud rural, servicios de salud mental, servicios de salud rural.

Mental health care is a complex and multidetermined field that involves a variety of theoretical and methodological frameworks, ethical stances and political positions. Reflecting on mental health - with special attention to health and living conditions of rural populations, to the modes of sociability shaping their everyday community lives, and to the knowledge, traditional practices and informal resources forming their therapeutic arsenal - raises a series of theoretical and methodological challenges in mental health care and management to the Brazilian Unified Health System (SUS).

Such challenges refer to the fact that rural populations are not homogeneous - there are differences in terms of social dynamics and subjects, population mobility, social relations, modes of production and cultural and environmental aspects. In these communities, social life and reproduction is related to the countryside, the forests and the aquatic environments. In other words, they are peasants; family farmers; settled or encamped rural workers; employees or temporary workers; traditional communities such as quilombolas, riverside dwellers, artisanal fisheries and shellfish gatherers; people who live in and use extractive reserves in forest and aquatic areas; people who are affected by dam construction; among others (Silva et al., 2015).
The dominant socio-economic model produces social costs that have an impact on the life, work and health of such populations. Working conditions in rural areas have generated an alarming epidemiological situation characterized by a high prevalence of musculoskeletal morbidities and mental disorders, as well as by an increasing use of chemical inputs and inadequate protection tools that cause accidents and severe intoxication. The poor living conditions of rural and forest populations are related to health problems such as intestinal parasitosis and diarrhea resulting from a lack of basic sanitation and access to water supply; high rates of infant mortality; and infectious diseases such as Chagas disease and leishmaniasis (Ministério da Saúde, 2011).

The debate over health care is still based on urban and ethnocentric premises; i.e., it is not sensitive to the socio-cultural characteristics of other environments. This is a result of the colonialist knowledge and practices adopted in the health care field, which contributes to the maintenance of iniquities that have shaped the history of rural populations. The current study ${ }^{2}$ dis-

The present study is part of a Master's research project whose general aim was to characterize and analyze mental health care services provided to 
cusses mental health care from the perspective of social determinants of health considering the concrete territories inhabited by rural populations. The territorial and community logic guiding psychosocial care must be introduced in the daily routine of health care teams. Such process will provide more effective solutions to the mental health needs of rural populations, which are directly related to the social iniquities that have shaped life in the countryside.

\section{Method}

We conducted a systematic review on mental health care in rural environments in the following databases: SciELO Brazil, Virtual Health Library (VHL Brazil) and Brazilian Digital Library of Theses and Dissertations (Biblioteca Digital Brasileira de Teses e Dissertações, BDTD). Such selection was based on the importance of these virtual databases for Brazilian publications. SciELO Brazil is an electronic library covering a selected collection of Brazilian scientific journals. VHL Brazil is part of the Virtual Health Library system, developed by the Latin American and Caribbean Center on Health Sciences Information (BIREME). BDTD is a web portal that gathers information systems of published theses and dissertations from Brazilian education and research institutions. The three databases were searched separately, with no exclusion criterion, since there is little research about the chosen topic. Articles, books and book chapters were found in the database search. It is important to note that in the following theoretical articulation we highlight some issues that confirm research information mentioned in the literature.

\section{Psychosocial and Environmental Vulnerabilities and Rural Mental Health}

The reproduction of rural poverty is directly related to a socio-economic model that guaran-

rural settlers in the state of Rio Grande do Norte, Brazil. tees the privileges of large agricultural companies. The space is organized according to their productive activity, and country estates and exploitation of rural workers are reproduced as fundamental pillars of the economic and social life in the countryside. Therefore, poverty has a great impact on rural populations - about $50 \%$ of them are facing poor living situations according to studies that have shown the predominance of poverty in rural areas (Kageyama \& Hoffmann, 2006; Rocha, 2006).

Despite the persistence of poverty, in the last two decades there has been a relatively strong income growth and a sharp decline in inequality in rural environments (Helfand, Rocha, \& Vinhais, 2009). The incipient improvement in the living conditions of rural populations as a result of land policies has alleviated social conflicts, but has not changed the situation of poverty and social inequality. The life journey of rural settlers is shaped by poor conditions of social reproduction and great difficulty in accessing health policies and programs, education, security, transportation, housing and organization of production (Dimenstein et al., 2014). We can infer, therefore, that the way rural settlements ${ }^{3}$ are arranged today is producing psychosocial and environmental vulnerabilities ${ }^{4}$.

3 The term in Portuguese, assentamento, first appeared in legal and sociological vocabulary in the context of the Venezuelan land reform in 1960, spreading to other countries later. Using the concept of Bergamasco and Norder (1996, p. 07), we understand rural settlements as "agricultural production units created by government policies aimed at reorganizing land use for the benefit of landless or almost landless rural workers" and the result of federal, state and municipal land policies.

4 To help us interpret situations of social vulnerability as various forms of exclusion of population groups from those experiences or benefits that are part of the global development process, we can expand the notion of vulnerability in order to understand it as social and environmental vulnerability. This concept deals with the spatial coexistence or overlap of groups in situation of poverty and high deprivation living in areas of environmental degradation or at risk (Cartier, Barcellos, Hübner, \& Porto, 2009). Therefore, vulnerable social groups who are subjected to risk 
The social, political and territorial characteristics of rural Brazil are associated with a number of phenomena such as forest devastation, loss of biodiversity, soil erosion, precariousness of labor relations, rural-urban migration, etc. All of them contribute to a situation of psychosocial and environmental vulnerability that has a direct impact on the life and health of rural populations with shortage of goods and social and material resources to face such risk factors (Pinheiro, Silva, Carneiro, Faria, \& Silva, 2009).

From this perspective, poverty, unequal land access and environmental factors have disseminated psychosocial effects on populations in the countryside. Hunger, violence, trauma, pain, humiliation and lack of recognition experienced by subordinate social groups can be considered mediators of various types of suffering. Thus, deprivation of multiple goods and services has a negative impact on the mental health of these groups (Silva \& Santana, 2012).

There are few studies on rural mental health at the international level (Ministerio de Sanidad $y$ Politica Social, 2011). In Brazil, one of the few studies about it, the National Confederation of Agricultural Workers report (CONTAG, 2013), identified as major health problems the following: back problems, hypertension, constant headaches, gastrointestinal disorders, allergy/ skin problems and insomnia. Such complaints indicate the presence of psychosocial suffering associated with rural living and working conditions.

According to the World Health Organization (WHO, 2010), situations of vulnerability produce a psychosocial impact on people. Stigmatization and marginalization can affect selfesteem and self-confidence, reduce motivation and interfere in life projects. Isolation and everyday exposure to violence and abuse can cause psychosomatic symptoms, use of psychoactive substances and serious mental health problems. Similarly, mental health is negatively affected when civil, cultural, political and social rights are violated, or when social groups are denied

factors related to their territory produce social and environmental vulnerabilities. opportunities of income generation and education, which leads to particular consequences for historically poor rural populations. An aggravating factor in situations of vulnerability is that mental health problems experienced by such groups usually are not addressed by national health systems.

Authors such as Costa, Dimenstein and Milk (2014) in their study with rural settlers say that a combination of socio-economic and environmental risks affects quality of life and health conditions producing suffering (e.g., common mental disorders). There is a number of issues, stressors and specific characteristics in rural areas associated with mental health problems, which means that resolution depends on the articulation of a variety of factors in the territories where different types of suffering are produced. Understanding mental health care based on socio-territorial dynamics and living and working conditions involves paying attention to the social determinants of health for rural populations.

\section{Composition of Psychosocial Care: Social Determinants of Health}

Currently in the mental health field, psychosocial care is considered a guiding strategy in the organization of care services and practices for a given community in a given territory (Amarante, 2007). However, we need to discuss to what extent the advances implemented by this new operating logic - intended to be paradigmatic - are actually corresponding to the health needs related to the singular territories of populations.

A psychosocial perspective of care involves expanding the concept of health in order to take into account the variety of determinants that produce health-disease processes. According to Basaglia (1979), mental suffering is also a matter of inequality, oppression, intolerance, marginalization and exclusion of individuals and populations. Therefore, from the viewpoint of social determinants of health, care practices cannot be restricted to biomedical and/or psychological variables.

The theoretical discussion on social determinants of health may provide elements for 
establishing care practices connected with the daily life of populations. Historically, the debate over social determinants in the health care field generated considerable criticism of the technicality, pragmatism and reductionism of the models that explained the health-disease process, as well as of knowledge produced in an ahistorical way, decontextualized from everyday life of populations.(Almeida-Filho, 2010; Bosi, Melo, Carvalho, Ximenes, \& Godoy, 2014; Buss \& Pellegrini, 2007; Fleury-Teixeira \& Bronzo, 2010; Garbois, Sodré, \& Dalbello-Araújo, 2014; Garrafa \& Cordon Portillo, 2009; Souza, Silva, \& Silva, 2013; Tambellini \& Schutz, 2009).

The concept of determinants became widely used by researchers and national and international organizations to reflect on the health-diseasecare process. In general terms, the idea is that living and working conditions of individuals and population groups affect their health. As highlighted in a WHO report (2003), determinants are used to understand the process of generation of health iniquities and to guide public policies regarding social inequality, stress, early life, social exclusion, labor, unemployment, social support, drug addiction, food and transportation.

Although authors emphasize certain social conditions that are considered health determinants, studies on social determinants of health are focused only on establishing causal correlations between social factors and health phenomena. Grounded in traditional epidemiology, whose aim is to identify connections between social variables and morbimortality events among different population groups, this analytical category strengthens the positivist perspective that was criticized at first (Almeida-Filho, 2010; Nogueira, 2010).

The category "determinant" - and its causal, linear and mechanical nature - disregards other means of producing the health-disease-care process, such as dialectical, cyclical, structural and other processes. Identifying the several factors that have an impact on the health-disease process is insufficient to explain health complexity, which makes it necessary to think of social determinants of health as a historical and cultural construction of living conditions and their mul- tiple determinants (Almeida-Filho, 2010; Breilh, 2010; Fleury-Teixeira \& Bronzo, 2010; Garbois et al., 2014).

The health-disease-care process of populations and individuals must be understood in terms of its multidetermined nature, as part of a socio-cultural context, influenced by a complex interaction of elements ranging from micro to macro levels. From this perspective, the category "territory" emerges as a basic notion to reflect on psychosocial care. Turning the territory into an ordering principle for care strategies means establishing a close connection between care services, social context and concrete living circumstances. Thus, organizing services and programs and developing care actions according to a territorial logic involve "looking at and listening to the life pulsing in that place" (Lima \& Yasui, 2014, p. 597). We infer then that social determinants of health are negotiated in the territories amid materialities that exist in the contexts of life, of established sociabilites, of a possible existence (Koga, 2015).

\section{Composition of Psychosocial Care: Developing a Territorial Logic of Care}

Theories about the notion of territory are related to geography, with an emphasis on the work of Milton Santos, for whom such theories are useful for social analysis when based on the use of the territory and the actors who use it. For the author, a living territory is a place of construction of personal, social, political and cultural relations that influence the ways of living of its inhabitants. As products and producers of social relations, territories are objects and agents of social change, i.e., they take on meaning through the dwelling of their residents (Santos, 2008).

Using the category "territory" to discuss psychosocial care means that we deal with modes of care that are connected with the social context in which life takes place, with the space where services must be anchored and with the ground on which such modes will be produced.

Turning the territory into an organizing principle of care practices requires a close con- 
nection with the social context of users and their concrete living circumstances, so that providing health care amid the established social conditions that can cause diseases becomes possible. Therefore, it is inexcusable to expand the perception and decentralize the attention from physiological and psychological care systems toward the moving complexity of the territory, its unique contexts and interactions. It is essential, however, to cultivate ways of understanding the health needs of populations and consider the determinants that each place has developed through the mediation of technical, popular and traditional knowledge (Almeida, 2015).

When rural settlers are able to overcome the difficulty of access to health and social care services, they are assisted with care models that are invariably insensitive to their peculiarities. For Rigotto et al. (2012), meeting the health needs of rural populations in terms of reception and care is a problem for health care services, since production processes, ways of life and forms of sociability specific to each territory and necessary for planning actions are not taken into account. Care practices are guided by vertical and decontextualized programs created by the ministries in charge.

Territory-based discussions must guide the implementation of health services in rural environments. This organization should be based on the materialities, flows and uses of each territory with the aim of providing comprehensive care. A small town in the northeastern semiarid region of Brazil differs in terms of network organization from localities in the Amazon region or the outskirts of a metropolis (Guimarães, Pickenhayn, $\&$ Lima, 2014). The model used for coordinating the network of services and actions directly affects groups living far from urban areas, such as rural populations, in terms of access.

Following this line of thought, Spain has tried to deal with socio-territorial characteristics and their experience may serve as inspiration for mental health care planning in rural environments. There, proposed solutions included the development of flexible programs with small teams working close to people and their every- day lives. Such approach goes beyond the traditional idea of mental health facilities characterized by inflexibility of the labor process in terms of staff circulation, service opening hours, referral protocols and staff allocation. It is worth noting that in Spain the organization of care networks in rural environments is based on meeting the needs of each territory, which results in specific care services, programs and strategies.

Some elements are involved in the working process of those services, such as: (a) protocols for detection of users in rural environments avoiding care failures; (b) guarantee of at least $20 \%$ of staff hours dedicated to actions in the territories; (c) home care programs aimed at rural environments; (d) high coordination among health services for geographically isolated cases with an emphasis on primary care; (e) enhancement of primary care coordination and use of social facilities from the territories; (f) attention to families in remote areas as a way to obtain cooperation for user care; and (g) staff continuous education to intervene in such environments contributing to the qualification of psychosocial programs and interventions (Ministerio de Sanidad y Politica Social, 2011).

The category "territory" is useful especially to reflect on everyday care practices in rural environments. When we accept that health needs are produced according to the concrete territories of populations, we denaturalize a common understanding of living conditions and health problems and start considering the social and environmental factors that affect these conditions. Other modes of care may be promoted with no restriction to health problems and range of symptoms. Moreover, such modes may interfere in the technical and biomedical care model that determines the adoption of individualistic and curative care practices encouraging a rampant demand for health services and creating a cycle of supply and demand for this type of isolated care (Franco \& Merhy, 2013).

For Ayres (2014), it is necessary to overcome reductionist perspectives about the healthdisease process of populations in vulnerable conditions. The complexity of the processes in- 
volved in their health conditions requires ways of understanding that do not make sense in light of the hegemonic paradigm in biomedical health care. The author believes in the use of technical care arrangements sensitive to the diversity and peculiarities of health needs with potential to adequately meet such needs.

Merhy (2013) proposes the collectivization of health care management drawing on the interest of users and their unique health needs. $\mathrm{He}$ says that soft technologies - referring to relational technologies in interceding spaces created between professionals and users - can coordinate health care practices establishing a routine based on singularities and emancipatory processes. Thus, creating dialogical spaces among relevant actors makes it possible to understand the peculiar characteristics of life in the countryside; the history of struggle for social reproduction and constitution of political subjects; the different ways of working the land; the structured sociabilities; the shared social networks; the family models that escape the traditional idea of a bourgeois family; the beliefs and religiousness; the different conceptions of health and popular care practices. As a result, populations are removed from a static, invariable and homogenizing territory, and placed in a dynamic, procedural and changeable territory.

\section{Psychosocial and Mental Health Care in Rural Environments: An Emphasis on Primary Care}

Taking into account the negative health rates of rural populations and the lack of public policies targeting them, the XII National Health Conference in 2004 identified as one of the main challenges of SUS ensuring access to the health care system for such populations (Bergamaschi, Teles, Souza, \& Nakatami, 2012). The Brazilian Ministry of Health created then the Land Working Group, which elaborated the National Comprehensive Health Care Policy for Rural, Forest and Water Populations (PNSIPCFA), introduced in 2011. It considers the particular characteristics of different Brazilian rural populations with the aim of promoting comprehensive and univer- sal access to health care, as well as incorporating into current health programs specific health needs of these populations.

Regarding mental health care, we analyzed the PNSIPCFA text and found that there are no proposed changes to the principles of the Psychosocial Care Network (RAPS) in the sense of taking into account the socio-territorial and psychosocial characteristics of rural populations. The policy seeks to reinforce the importance of RAPS and analyzes epidemiological aspects associated with rural work identified as suffering triggers. Similarly, in the current mental health care policy there is no established guideline that could meet the specific needs of rural populations. Given the socio-territorial characteristics of rural populations and their specific health needs, a paradoxical radicalization of the very principles that organize psychosocial care in Brazil is required. If psychosocial care required a transformation of power relations, new articulations among actors and deconstruction of knowledge, practices and cultures related to the asylum model, now its own knowledge, practices and cultures are challenged given the peculiarities associated with rural populations (Assis et al., 2014).

Despite a lack of direct reference to mental health care, among PNSIPCFA main guidelines is the appreciation of "traditional practices and knowledge promoting the recognition of the subjective, collective and social dimensions of such practices and the production and reproduction of knowledge of traditional populations" (Ministério da Saúde, 2011, p. 6). The appreciation of popular knowledge and traditional health practices shows a commitment to the production and reproduction of knowledge of traditional populations, such as midwives, faith healers, herbal healers, shamans, etc.

Despite being subjected to processes of social marginalization, rural populations preserve their knowledge and practices, which foster a sense of belonging and organize their ways of understanding and acting in the world. The cultural aspect, which includes popular beliefs, religiousness, food and sociability, creates ways of dealing with diseases and relieves pain and suf- 
fering (Budó \& Saupe, 2005; Escola de Saúde Pública de Minas Gerais, 2014; Lara, Brito, \& Rezende, 2012). The enhancement of cultural and informal care practices becomes an important focus for professionals who work in these environments, since they are the first steps taken by users with diseases (Silva, Dimenstein, \& Leite, 2013).

In addition to the appreciation of traditional knowledge, for psychosocial care the community is an important locus for investment in health care actions. Professionals may encourage community initiatives that serve as support for individuals. Juliano and Yunes (2014) define social support networks as groups of significant systems and people that constitute the relations received and perceived by individuals. Affection is crucial in this context due to its unquestionable value to the establishment and maintenance of support networks. Given the situations of poverty and vulnerability experienced by part of rural populations, the effectiveness of support networks can function as a coping mechanism to deal with adverse living conditions, as well as social protection.

According to Vasconcelos (2013), community cooperatives, rural workers' associations, rural social movements, and even faith-based groups and neighborhood circles can be considered mutual support groups, since they provide opportunities for exchanging experiences, sharing life stories, giving advice and emotional support and discussing strategies to face everyday problems (mutual aid), as well as care actions and concrete support (mutual support). For Vasconcelos (2013), such groups and friendship networks are considered important strategies of empowerment, i.e., they are responsible for encouraging power increase and personal and collective autonomy before situations of oppression, violence or discrimination. The establishment and maintenance of social ties among people who share the same space in a community indicates greater social cohesion, reciprocal exchanges and social support, which are protective factors against diseases (Almeida, 2015).

From this perspective, for rural populations primary health care is considered a level of care that allows an immersion in the territory where people live and the recognition of health needs and processes of social determinants of health. Through the establishment of ties and user accountability, it raises possibilities for establishing a system of relational and singular care contributing to more resolutive and consistent responses to local problems.

Studies on access to primary care and quality of care of rural populations (Oliveira et al., 2015; Uchoa et al., 2011) highlight a significant improvement in living conditions following the expansion of primary care, particularly with regard to prenatal care, child growth and development, control of diabetes and hypertension, and expansion of dental care. There are few studies concerning mental health care in rural environments, but evidence from experiences in Spain clearly shows the importance of primary care to communities that live far from urban areas, such as rural populations (Ministerio de Sanidad y Politica Social, 2011).

In a study conducted in rural environments, Oliveira et al. (2015) observed that primary care teams based their actions on interdisciplinary and intersectoral perspectives with greater involvement of users in the organization of care and community action planning. They emphasized that, after understanding the direct connection between health and land as a material and symbolic living condition of these populations, care teams have been focused on enhancement of facilities and collective support services for families, such as housing, telephone systems and mobility. Such factors can significantly affect living and health conditions, as well as the decision of staying or leaving the countryside.

Thus, we highlight that primary care enables the articulation of a community care network connecting different social and institutional facilities. Such network paves the way not only for the modification of forms of care and user support, but also allows the establishment of new relations and sociabilities in the communities. Based on international experiences, Dimenstein (2013) reports the importance of primary care for the development and expansion of care strategies including issues such as community 
life and work. In other words, integrating mental health into primary health care is necessary for the sustainability of the psychiatric reform (Dimenstein, Lima, \& Macedo, 2013; Figueiredo \& Campos, 2009).

Most Brazilian municipalities do not meet the population criterion (i.e., they have less than 15,000 inhabitants) required for the implementation of services such as the Centers for Psychosocial Care (CAPS), which means that primary care is the most important reference in terms of mental health for most rural populations. This level of care includes several public policies, such as PNSIPCFA, mental health policies, social care policies, etc. Primary care actions make it possible to consider health care in comprehensive terms, to recognize the determinants that affect health conditions, to identify gaps where interventions can produce greater impact on the health of populations, and to tackle the various factors that make life difficult for families and communities (Buss \& Pellegrini, 2007).

\section{Final Considerations}

We found few national and international studies on mental health care for rural populations. Health care, and more specifically mental health care, has been shaped by a model based on technification, objectification, biologicism, mechanicism, hospital centrism, curativism and specialism. The perspective of social determinants of health, as well as territory studies, provides theoretical and methodological resources that may contribute to a broader understanding of the health-disease-care process, especially in rural environments, strengthening the psychosocial care logic that guides the Brazilian psychiatric reform. Psychosocial and mental health care has the following characteristics: it is produced in the territory; it is sustained by singular care technologies; it is contextualized; and it is culturally sensitive and ethically committed to the lives of rural populations. Therefore, it has great potential to address health iniquities and social and environmental vulnerabilities historically experienced in the countryside. Finally, we high- light that the primary care level is where psychosocial and mental health care has more chances of being coproduced between health professionals and rural residents through the articulation of knowledge and technologies.

\section{References}

Almeida, K. S. de. (2015). Urbanização e modos de vida: Debate sobre determinação social da saúde (Master's thesis, Universidade Federal do Rio Grande do Norte, Natal, RN, Brazil).

Almeida-Filho, N. (2010). A problemática teórica da determinação social da saúde. In N. Nogueira (Ed.), Determinação social da saúde e reforma sanitária (pp. 13-36). Rio de Janeiro, RJ: Centro de Estudos Brasileiros de Saúde.

Amarante, P. (2007). Saúde mental e atenção psicossocial. Rio de Janeiro, RJ: Fundação Oswaldo Cruz.

Assis, J. T. de, Barreiros, C. A., Jacinto, A. B. M., Kinoshita, R. T., de Lemos Macdowell, P., \& Mota, T. D. (2014). Política de saúde mental no novo contexto do Sistema Único de Saúde: Regiões e redes. Saúde em Debate, 52, 88-113.

Ayres, J. R. (2014). Vulnerabilidade, direitos humanos e cuidado: Aportes conceituais. In S. Barros, P. F. S. Campos, \& J. J. S. Fernandes (Eds.), Atenção à saúde de populações vulneráveis (pp. 1-25). Barueri, SP: Manole.

Basaglia, F. (1979). Psiquiatria Alternativa: Contra o pessimismo da razão, o otimismo da prática. São Paulo, SP: Brasil Debates.

Bergamaschi, F. P. R., Teles, S. A., Souza, A. C. S., \& Nakatami, A. Y. K. (2012). Reflexões acerca da integralidade nas reformas sanitária e agrária. Texto \& Contexto Enfermagem, 21(3), 667-674. doi:10.1590/S010407072012000300023

Bergamasco, S. M. P., \& Norder, L. A. (1996). O que são assentamentos rurais. São Paulo, SP: Brasiliense.

Bosi, M. L. M., Melo, A. K. D. S., Carvalho, L. B., Ximenes, V. M., \& Godoy, M. G. C. (2014). Determinantes sociais em saúde (mental): Analisando uma experiência não governamental sob a ótica de atores implicados. Revista Brasileira de Epidemiologia, 17(Suppl. 2), 126-135. doi:10.1590/1809-4503201400060011 
Breilh, J. (2010). Las tres 'S'de la determinación de la vida: 10 tesis hacia una visión crítica de la determinación social de la vida y la salud. In $\mathrm{N}$. Nogueira (Ed.), Determinação social da saúde e reforma sanitária (pp. 87-125). Rio de Janeiro, RJ: Centro de Estudos Brasileiros de Saúde.

Budó, M. D. L. D., \& Saupe, R. (2005). Modos de cuidar em comunidades rurais: A cultura permeando o cuidado de enfermagem. Texto Contexto Enfermagem, 14(2), 177-185. doi:10.1590/ S0104-07072005000200004

Buss, P. M., \& Pellegrini, A., Filho. (2007). A saúde e seus determinantes sociais. Physis, 17(1), 77-93. doi:10.1590/S0103-73312007000100006

Cartier, R., Barcellos, C., Hübner, C., \& Porto, M. F. (2009). Vulnerabilidade social e risco ambiental: Uma abordagem metodológica para avaliação de injustiça ambiental. Cadernos de Saúde Pública, 25(12), 2695-2704.

Costa, M. G. S. G., Dimenstein, M., \& Leite, J. F. (2014). Condições de vida, gênero e saúde mental entre trabalhadoras rurais assentadas. Estudos de Psicologia (Natal), 19(2), 145-154. doi:10.1590/S1413-294X2014000200007

Dimenstein, M. (2013). La reforma psiquiátrica y el modelo de atención psicosocial en Brasil: en busca de cuidados continuados e integrados en salud mental. Revista CS, (11), 43-72.

Dimenstein, M., Leite, J., Macedo, J. P., Borges, J. A., Sabadini, M. A., Gomes, M. G., ...Belarmino, V. (2014). Condições de vida e saúde mental em assentamentos de reforma agrária no nordeste brasileiro. In P. Santana \& P. Nossa, P. (Eds.), A Geografia da Saúde no cruzamento de saberes (pp. 113-116). Coimbra, Portugal: Grupo de Investigação em Geografia da Saúde.

Dimenstein, M., Lima, A. I., \& Macedo, J. P. (2013). Integralidade em saúde mental: Coordenação e continuidade de cuidados na Atenção Primária. In S. Paulon \& R. Neves. (Eds.), Saúde Mental na Atenção Básica: A territorialização do cuidado. Porto Alegre: RS: Sulina.

Escola de Saúde Pública de Minas Gerais. (2014). Cuidados em Saúde Mental: Diálogos entre o MST e o SUS. Belo Horizonte, MG: Author.

Figueiredo, M. D., \& Campos, R. O. (2009). Saúde Mental na atenção básica à saúde de Campinas, SP: Uma rede ou um emaranhado?. Ciência \& Saúde Coletiva, 14(1), 129-138. doi:10.1590/ S1413-81232009000100018
Fleury-Teixeira, P., \& Bronzo, C. (2010). Determinação social da saúde e política. In N. Nogueira (Ed.), Determinação social da saúde e reforma sanitária (pp. 37-59). Rio de Janeiro, RJ: Centro de Estudos Brasileiros de Saúde.

Franco, T. B., \& Merhy, E. E. (2013). A produção imaginária da demanda e o processo de trabalho em saúde. In T. B. Franco \& E. E. Merhy, Trabalho, produção do cuidado e subjetividades em saúde (pp. 199-213). São Paulo, SP: Hucitec.

Garbois, J. A., Sodré, F., \& Dalbello-Araujo, M. (2014). Determinantes sociais da saúde: O "social” em questão. Saúde Sociedade, 23(4), 11731182. doi:10.1590/S0104-12902014000400005

Garrafa, V., \& Cordon Portillo, J. A. (2009). Determinantes sociais da doença. Saúde Debate, 33(83), 388-397.

Guimarães, R. B., Pickenhayn, J. A., \& Lima, S. C. (2014). Geografia e saúde sem fronteiras. Uberlândia, MG: Assis.

Helfand, S. M., Rocha, R., \& Vinhais, H. E. (2009). Pobreza e desigualdade de renda no Brasil rural: Uma análise da queda recente. Pesquisa $e$ Planejamento Econômico, 39(1), 59-80.

Juliano, M. C. C., \& Yunes, M. A. M. (2014). Reflexões sobre rede de apoio social como mecanismo de proteção e promoção de resiliência. Ambiente \& Sociedade, 17(3), 135-154.

Kageyama, A., \& Hoffmann, R. (2006). Pobreza no Brasil: Uma perspectiva multidimensional. Economia e Sociedade, 15(1), 26.

Koga, D. (2015). Territórios de vivência em um país continental. Serviço Social \& Saúde, 14(119), 9-26.

Lara, M. O., Brito, M. J. M., \& Rezende, L. C. (2012). Aspectos culturais das práticas dos Agentes Comunitários de Saúde em áreas rurais. Revista da Escola de Enfermagem USP, 46(3), 673-680. doi:10.1590/S0080-62342012000300020

Lima, E. M. F. A. de, \& Yasui, S. (2014). Territórios e sentidos: Espaço, cultura, subjetividade e cuidado na atenção psicossocial. Saúde Debate, 38(102), 593-606.

Merhy, E. E. (2013). Um ensaio sobre o médico e suas valises tecnológicas: Contribuições da análise do território tecnológico do trabalho vivo em ato em saúde para compreender as reestruturações produtivas do setor saúde. In T. B. Franco \& E. E. Merhy, Trabalho, produção do 
cuidado e subjetividades em saúde (pp. 95-108). São Paulo, SP: Hucitec.

Ministerio de Sanidad y Politica Social. (2011). Rehabilitación psicosocial de pesonas con trastorno mental grave. Pautas de intervención en el domicilio y programas para contextos rurales. Castilla-La Mancha, España: Author.

Ministério da Saúde. (2011). Política nacional de saúde integral às populações do campo e da floresta. Brasília, DF: Secretaria-Geral da Presidência.

National Confederation of Agricultural Workers. (2013). Relatório da "Escuta Itinerante: Acesso dos povos do Campo e da Floresta ao SUS". Retrieved from http://www.contag.org.br/index.ph p? modulo $=$ portal $\&$ acao $=$ interna $\&$ codpag $=101$ $\& \mathrm{id}=9668 \&$ data $=11 / 06 / 2014 \& \mathrm{nw}=1 \& \mathrm{mt}=1 \&$ in $=1$

Nogueira, N. (2010). Determinação social da saúde e reforma sanitária. Rio de Janeiro, RJ: Centro de Estudos Brasileiros de Saúde.

Oliveira, E. M. de, Felipe, E. A., Santana, H. da S., Rocha, I. H., Magnabosco, P., \& Figueiredo, M. A de C. (2015). Determinantes sócio-históricos do cuidado na Estratégia Saúde da Família: A perspectiva de usuários da área rural. Saúde $e$ Sociedade, 24(3), 901-913.

Pinheiro, T. M., Silva, J. M., Carneiro, F., Faria, H., \& Silva, E. (2009). Saúde no campo. In A. Miranda (Coord.), Cadernos de textos da $1^{a}$ Conferência Nacional de Saúde Ambiental (pp. 25-29). Brasília, DF: Associação Brasileira de Saúde Coletiva.

Rigotto, R. M., Carneiro, F., Ferreira, M. A., Rocha, M., Ferreira, M., Pessoa, V., ...Teixeira, M. M. (2012). O verde da economia no campo: Desafios à pesquisa e às políticas públicas para a promoção da saúde no avanço da modernização agrícola. Ciência \& Saúde Coletiva, 17(6), 1533 1542. doi:10.1590/S1413-81232012000600017

Rocha, S. (2006). Pobreza e indigência no Brasil Algumas evidências empíricas com base na PNAD 2004. Nova Economia, 16(5), 265-299.

Santos, M. (2008). Por uma outra globalização: Do pensamento único à consciência universal. Rio de Janeiro, RJ: Record

Silva, F. C. M., Deus, G. G., Blumm, I. M. L., Souto, K. M. B., Silva, M. G. C. S., Lied, T. B., ...Corrêa, V. S. (2015). A Política Nacional de Saúde Integral das populações do campo, da floresta e das águas e o ambiente. In Ministério da Saúde, Saúde e ambiente para as populações do campo, da floresta e das águas (pp. 9-24). Brasília, DF: Ministério da Saúde.

Silva, V. H F. da, Dimenstein, M., \& Leite, J. F. (2013). O cuidado em saúde mental em zonas rurais. Mental, 10(19), 267-285.

Silva, D. F., \& Santana, P. R. (2012). Transtornos mentais e pobreza no Brasil: Uma revisão sistemática. Tempus - Actas de Saúde Coletiva, 175-185.

Souza, D. O. de, Silva, S. E. V., \& Silva, N. O. de. (2013). Determinantes sociais da saúde: Reflexões a partir das raízes da" questão social". Saúde e Sociedade, 22(1), 44-56.

Tambellini, A. T., \& Schütz, G. E. (2009). Contribuição para o debate do Cebes sobre a "Determinação Social da Saúde": Repensando processos sociais, determinações e determinantes da saúde. Saúde em Debate, 33(83), 371-379.

Uchoa, A. D. C., Souza, E. L., Spinelli, A. F. S., Medeiros, R. G. D., Peixoto, D. C. D. S., Silva, R. A. R. D., ...Rocha, N. S. P. (2011). Avaliação da satisfação do usuário do Programa de Saúde da Família na zona rural de dois pequenos municípios do Rio Grande do Norte. Physis, 21(3), 1061-1076. doi:10.1590/S010373312011000300016

Vasconcelos, E. M. (2013). Manual [de] ajuda e suporte mútuos em saúde mental: Para facilitadores, trabalhadores e profissionais de saúde e saúde mental. Rio de Janeiro, RJ: Escola do Serviço Social da Universidade Federal do Rio de Janeiro.

World Health Organization. (2003). Social determinants of health: The solid facts. Retrieved from http://www.euro.who.int/ data/assets/pdf file/0005/98438/e81384.pdf

World Health Organization. (2010). Mental health and development: Targeting people with mental health conditions as a vulnerable group. Retrieved from http://apps.who.int/iris/bitstre am/10665/44257/1/9789241563949_eng.pdf 